\title{
Ledermanniella yiben sp. nov. (Podostemaceae), Critically Endangered at the proposed Yiben Reservoir, Sierra Leone
}

\author{
Martin Cheek ${ }^{1}$ (D) Xander van der Burgt ${ }^{1}$, Joseph Momoh $^{2}$ \& Aiah Lebbie $^{3}$
}

Summary. Ledermanniella yiben Cheek is described from the Seli (Rokel) river bed at a single rapid to be flooded by the proposed Yiben hydroelectric dam and reservoir in Sierra Leone. It is assessed as Critically Endangered using the IUCN categories and criteria. The species appears to be unique among African Podostemaceae in bearing dimorphic shoots having either cupuliform or short ribbon-like leaves.

Key Words. Dimorphy, extinction, homology, hydroelectric reservoir, point-endemic.

\section{Introduction}

In the course of a botanical baseline survey for the proposed Yiben Hydroelectric Dam on the Seli River, upriver of the Bumbuna Dam, Sierra Leone, in April 2016, the second and third authors encountered a species of Podostemaceae, van der Burgt 1992. The plants were scattered densely along the gneissic rock bed of the river, then at its seasonal lowest level, largely dry, and with only a small channel of moving water, it being the end of the dry season. The plants were $20-50 \mathrm{~cm}$ diameter, spaced at distances of up to $50 \mathrm{~cm}$ apart from each other, with bare gneissic base rock in between, and appear restricted to the vicinity of a single set of rapids.

The 8-ribbed, non-compressed, unilocular, terete ovaries and fruits, each with two stigmas, the flowers inverted within the spathellum and the absence of flattened scale-leaves, indicate that this plant is placed within the genus Ledermanniella Engl. in the sense of Schenk et al. (2015), or, Ledermanniella subgenus Ledermanniella in the sense of Cusset (1984). Identification work at $\mathrm{K}$ failed to match van der Burgt 1992 with any known species of the genus (see Results, below). Consequently in this paper it is formally named as Ledermanniella yiben Cheek.

Podostemaceae are a pantropical family of annual or perennial herbs. All species of the family are restricted to rocks in rapids and waterfalls of clearwater rivers, and are therefore rheophytes. However this very habitat is being increasingly exploited for hydropower at some risk to the survival of the Podostemaceae they contain (Schenk et al. 2015;
Cheek et al. 2015; Cheek \& Ameka 2016). Most of the African species of Podostemaceae are narrow endemics, many being known from only a single waterfall. New discoveries of species are still being made frequently (Schenk et al. 2015; Cheek \& Haba 2016; Cheek et al. 2015; Cheek \& Ameka 2008, 2016; Kita et al. 2008; Beentje 2005; Schenk \& Thomas 2004; Cheek 2003, Rial 2002). Important characters in defining genera in Podostemaceae are the position of the flower in the unruptured spathellum, and the shape, and sculpture of the ovary. At species level, important characters are the shape and relative proportions of spathellae, stigmas, anthers, filaments, gynophores, pedicels, and leaves.

The current generic classification of African Podostemaceae is based on the framework established by Cusset (1973, 1974, 1978, 1983, 1984, 1987). This work has been compiled and updated by Rutishauser (2004). Recently, combined morphological and molecular phylogenetic studies of African Podostemaceae have shown that Ledermanniella (as delimited by Cusset) is paraphyletic, including all other sampled genera of Podostemaceae recognised in Africa. This was revealed by Thiv et al. (2009), employing plastid markers matK, trnD-trn $\mathrm{T}, \quad r p o \mathrm{~B}-\operatorname{trn} \mathrm{C}$ in sampling 9 genera and 17 species of African Podostemaceae, and Schenk et al. (2015), employing plastid markers $m a \mathrm{tK}, t r n \mathrm{~L}, r p o \mathrm{~B}-t r n \mathrm{C}, n d h \mathrm{~F}, r b c \mathrm{~L}$ and $m a t \mathrm{R}$ in sampling 10 genera and 27 species of African Podostemaceae.

In recent years the accumulated molecular phylogenetic data (Thiv et al. 2009; Schenck et al. 2015) has shown that Ledermanniella subg. Phyllosma C. Cusset

\footnotetext{
Accepted for publication 25 April 2017. Published online 5 June 2017

1 Herbarium, Royal Botanic Gardens, Kew, Richmond, Surrey, TW9 3AE, UK. e-mail: m.cheek@kew.org

2 Conservation and Wildlife Management Unit, National Protected Area Authority, Ministry of Agriculture, Forestry and Food Security, Freetown, Sierra Leone.

${ }^{3}$ National Herbarium of Sierra Leone, Department of Biological Sciences, Njala University, Njala, Sierra Leone.
} 
(1984) merits elevation to genus level as the resurrected genus Inversodicraea Engl. The transfer of names to effect this was recently completed (Cheek \& Haba 2016). The generic status of the remaining African taxa is not clear, since most of the recognised African genera are embedded within the remainder of Ledermanniella (formerly Ledermanniella subg. Ledermanniella). Additional molecular sampling and analysis of taxa is needed to resolve relationships further.

A most remarkable feature of van der Burgt 1992 is that the shoots arising from the massive, long, branched main stems are dimorphic in their leaves and phyllotaxy. The two shoot types are:

1. Vegetative shoots of distichous phyllotaxy with narrowly ribbon-like and slightly channelled leaves.

2. Fertile shoots terminating in a spathellum subtended by opposite and decussate, very inconspicuous, cupuliform leaves.

These features are treated at length in the Discussion section.

\section{Methodology}

Abundant herbarium material, with photographs, was collected as van der Burgt 1992. Duplicates were deposited in Sierra Leone at FBC and SL and once authorisations had been obtained, the specimens were exported to $\mathrm{K}$ for identification by specialists, with other specimens resulting from the baseline botanical survey of the proposed Yiben dam area. Here it was examined with a Leica Wild M8 dissecting binocular microscope fitted with an eyepiece graticule measuring in units of $0.025 \mathrm{~mm}$ at maximum magnification. The drawing was made with the same equipment with a Leica 308700 camera lucida attachment.

The key used to attempt identification of the specimen was that of Cusset (1984). The specimen was compared with authoritatively named reference material at $\mathrm{K}$, or illustrations and descriptions, of every known species of Ledermanniella. The format of the description follows Cusset (1984). All specimens cited have been seen. The conservation assessment follows the IUCN (2012) standard. Herbarium codes follow Index Herbariorum (continuously updated). Plant names and authorities follow IPNI (continuously updated).

\section{Results}

The first couplet of the key to the species of Ledermanniella subg. Ledermanniella of Cusset (1984) is "Leaves with sheath very enlarged, cupuliform, membranous" (lead 1), vs "leaves with sheath non cupuliform" (lead 2). Ledermanniella yiben is unusual, possibly unique, in having both types of structure on the same plant.
If the first lead of couplet 1 is taken, we are led to the second couplet, the first lead of which fits our material: "blade reduced to a small mucron on the back of the sheath; flowers sessile on the thallus" leading to Ledermanniella aloides (Engl.) C. Cusset. However, van der Burgt 1992 (L. yiben) differs from this species in that it appears to lack an extensive thallus, but possesses instead massive lengthy aerial stems (Fig. 1), which do not occur in L. aloides. It also differs in that the cupuliform leaves lack stipules and that the mucro (reduced blade) is rarely seen, while in L. aloides stipules are present and the blade, while reduced, is conspicuous in over $90 \%$ of the leaves. The new species also differs in having one stamen (vs two in L. aloides) and in having short, sterile shoots with ribbon-like leaves (absent in L. aloides).

If the second lead of couplet 1 is followed ("leaves with sheath non cupuliform") and we set aside the cupuliform leaves seen in our material, Ledermanniella yiben keys out to couplet 14, by virtue of the bases of its ribbon-like leaves being non-cupuliform, the leaf apices being entire, the leaves arising along the length of a well-developed stem, leaves less than $2 \mathrm{~cm}$ long, and stamens one, closely matching the lead to L. jaegeri C. Cusset of Mt Loma (Sierra Leone): "Leaves filiform, base not enlarged, $3-5 \mathrm{~mm}$ long, stamen shorter than the ovary, pollen in dyads". Despite the fact that in van der Burgt 1992 (L. yiben) the stamen is longer than the ovary, L. jaegeri seems to be the species which most closely matches it. However, the differences, set out in Table 1 below, are so numerous that there is no doubt that they are different species. Accordingly, the species represented by van der Burgt 1992 is formally described and named below as Ledermanniella yiben.

Ledermanniella yiben Cheek sp. nov. Type: Sierra Leone, Koinadugu Distr., proposed Yiben Reservoir area, large rapids in Seli R., N of Yara village, $9^{\circ} 16^{\prime}$ 9.0"N; 11 ${ }^{\circ} 34^{\prime} 50.6^{\prime \prime} \mathrm{W}, 300 \mathrm{~m}$ a.s.l., fl., fr., 6 April 2016, van der Burgt 1992 (holotype $\mathrm{K}$; isotypes $\mathrm{BM}, \mathrm{BR}, \mathrm{FBC}$, G, MO, P, SL, WAG, Z).

http://www.ipni.org/urn:lsid:ipni.org:names:77161646-1

Rheophytic, probably perennial herb; forming mounds $20-50 \mathrm{~cm}$ diam., composed of numerous sprawling or suberect stems radiating from a central holdfast (thallus) when exposed in dry season by low water. Stems 10 - $30 \mathrm{~cm}$ long, fleshy-rubbery, brown outside, green inside, drying black, irregularly cylindrical 0.5 $1 \mathrm{~cm}$ diam., each with one or two main branches which in the distal parts branch repeatedly; rarely with naked filiform extension shoots $3-7 \mathrm{~cm}$ long, c. $2-$ $3 \mathrm{~mm}$ diam. Shoots and leaves dimorphic, thickly covering upper parts of the stem surface. Vegetative 

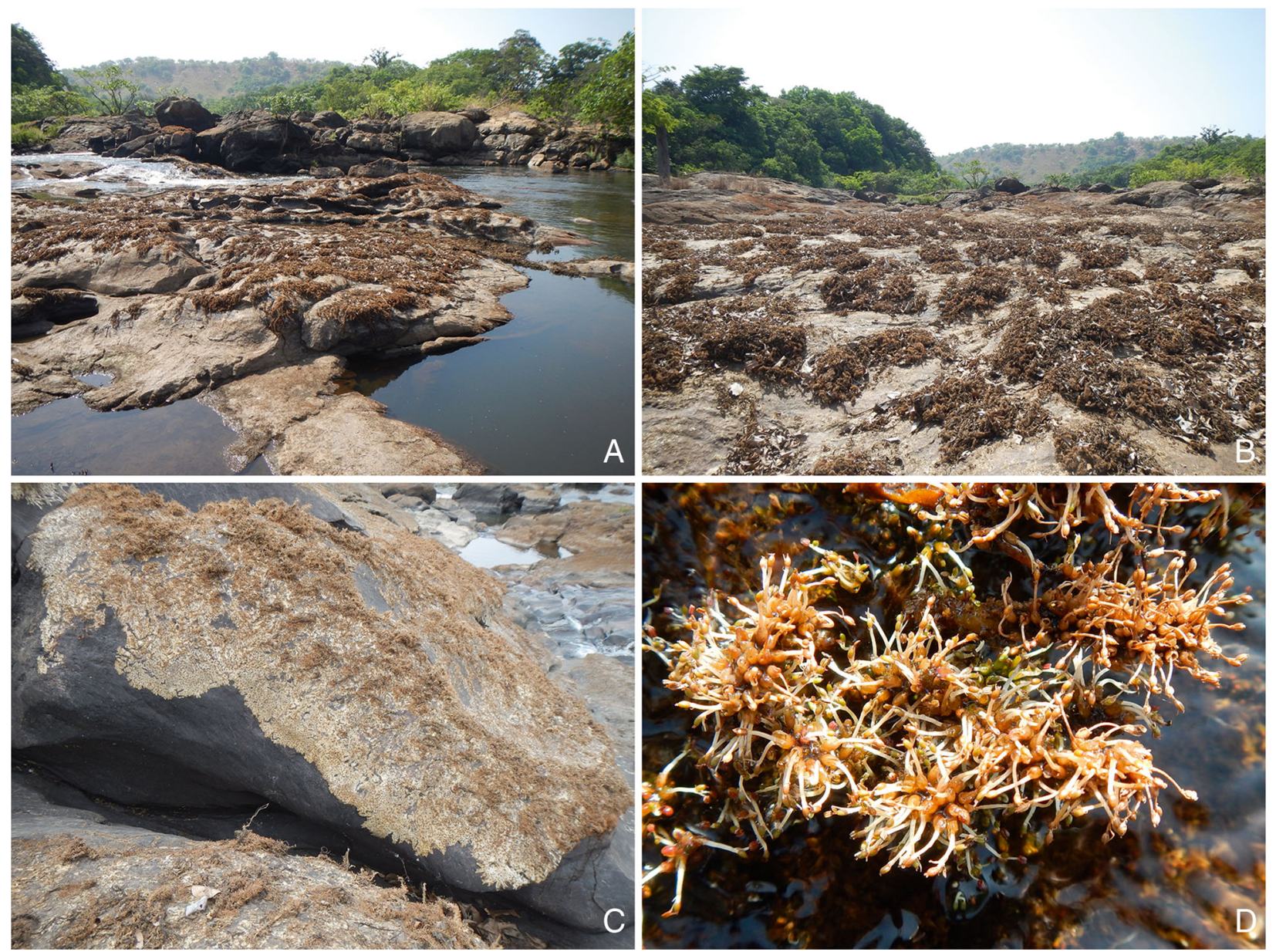

Fig. 1. Ledermanniella yiben at its only known locality in the Seli (Rokel) river within the proposed Yiben reservoir, 6 April 2016. A, $\mathbf{B}$ dried plants on flat bedrock in the river bed; $\mathbf{C}$ several individual plants; $\mathbf{D}$ part of a half-submerged plant in flower and fruit. PHOTOS: XANDER VAN DER BURGT.

shoots infrequent, erect (Fig. 2A \& B), most numerous towards the apex of the main stems, $5-10(-30) \mathrm{mm}$ long, (3-) 5 (-7) leaves per shoot, each leaf sheathing that above, arranged distichously, $3-7 \mathrm{~mm}$ long, erect, narrowly ribbon-shaped and shallowly canaliculated (channelled), tapering towards the acute apex, base sheathing, but lacking stipule lobes, elongated and not cupular. Fertile shoots sessile, erect, sometimes intermixed with sterile shoots, but usually in dense crustose masses completely covering large sections of the stem up to 10 or $15 \mathrm{~cm}$ long; each with a single terminal spathellum subtended by $2-3$ pairs of inconspicuous approximately opposite and decussate cupuliform (shallowly concave), suborbicular leaves $1 \mathrm{~mm}$ long, best observed in the developing shoots (Fig. 2G). Spathellum (with inverted flower bud)

Table 1. Diagnostic characters separating Ledermanniella jaegeri and L. yiben.

\begin{tabular}{|c|c|c|}
\hline Character & Ledermanniella jaegeri & Ledermanniella yiben \\
\hline Stamen length & Shorter than ovary & Longer than ovary \\
\hline Cupuliform leaves & Absent & Subtending spathellum \\
\hline Elongate leaves: insertion & $\begin{array}{l}\text { Spirally inserted on short shoots } \\
\text { which terminate in a spathellum }\end{array}$ & $\begin{array}{l}\text { Distichous on short shoots which } \\
\text { are sterile: spathellae absent }\end{array}$ \\
\hline Elongate leaves: shape & Terete (filiform) & $\begin{array}{l}\text { Dorsiventrally flattened (ribbon-like) } \\
\text { and slightly channelled. }\end{array}$ \\
\hline Styles & $\begin{array}{l}\text { Filiform, } 0.2-0.3 \mathrm{~mm} \text { long, } \\
\text { not united at base }\end{array}$ & $\begin{array}{l}\text { Ellipsoid, } 0.3-0.4 \mathrm{~mm} \text { long, united } \\
\text { at base }\end{array}$ \\
\hline Spathellum shape & Subobovoid & Ellipsoid-cylindrical \\
\hline Pollen & Dyads & Monads \\
\hline
\end{tabular}




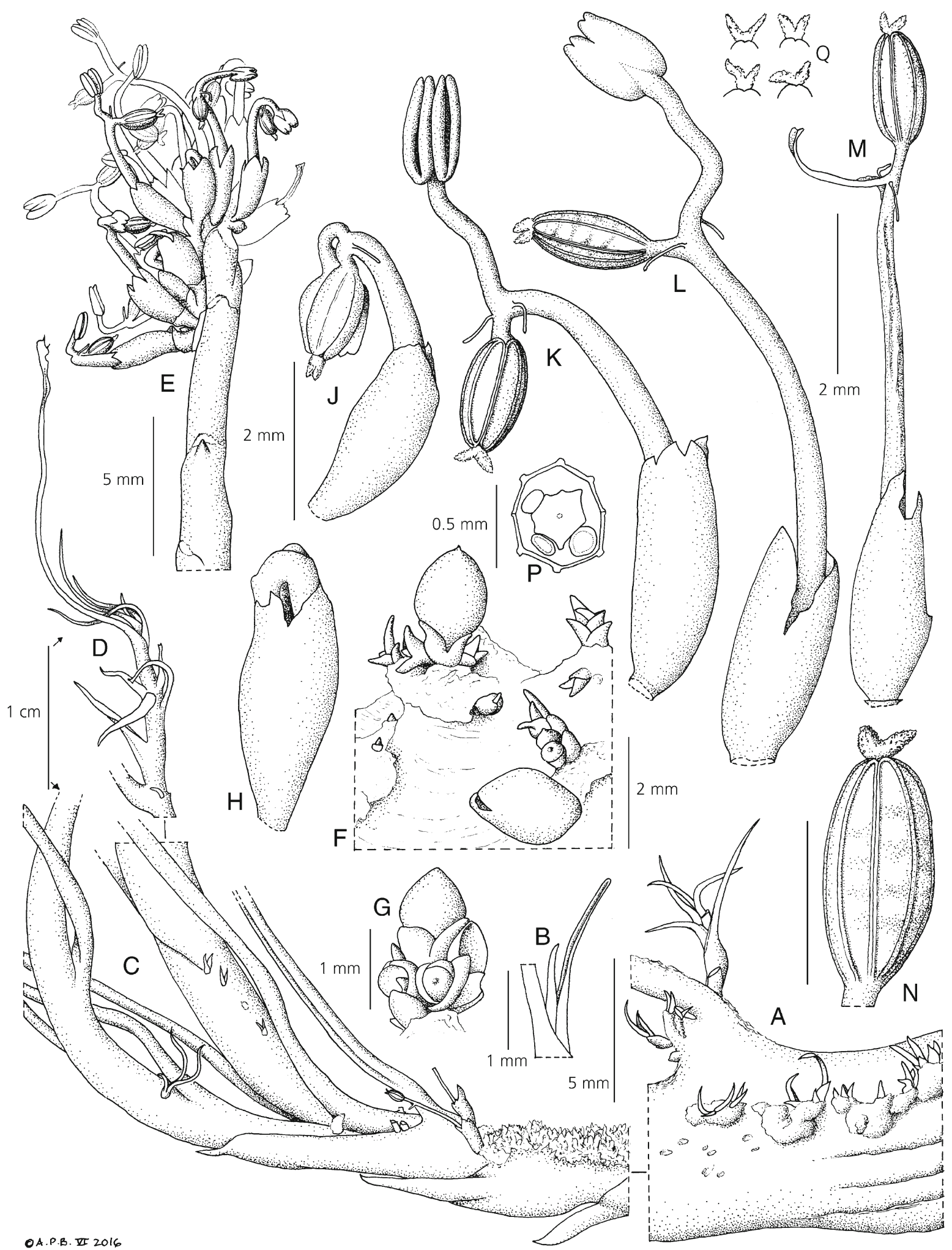

Fig. 2. Ledermanniella yiben. A habit, mid region of main axis of plant showing lateral vegetative short shoots; B detail of vegetative short shoot, showing distichous, slightly channelled leaves; C main axis, distal region, showing dense mass of fertile shoots (right) and numerous branches (left); $\mathrm{D}$ apex of main axis showing branches and vegetative short shoot; $\mathrm{E}$ stem branch with mass of fertile shoots terminating in flowers at anthesis; $F$ detail from $C$ showing multiple fertile shoots; $G$ cluster of immature fertile shoots; $\mathrm{H}-\mathrm{M}$ spathellum with flowers showing stages from spathellum rupture to post-anthesis; $\mathrm{N}$ detail of gynoecium; $\mathrm{P}$ transverse section of ovary; Q variation in stigma size, shape and orientation. All from van der Burgt 1992. DRAWN BY ANDREW BROWN. 
elliptic-cylindrical $1.4-2.4(-3.2) \times 0.7-1.2 \mathrm{~mm}$, apex rounded, very rarely with a mucro, base contracted, rarely with a short stipe, opening at the apex by three more or less equal triangular lobes or sometimes irregularly, each c. $0.4 \times 0.4 \mathrm{~mm}$; pedicel erect, angular-terete, white, $6.0-6.8 \mathrm{~mm}$ long, $0.2-0.3 \mathrm{~mm}$ diam. Tepals two, patent, cylindric, $0.3-0.5 \times 0.02 \mathrm{~mm}$ long, inserted opposite filament at base of gynophore. Androecium exceeding ovary, with a single stamen, filament $1.8-2.5 \mathrm{~mm}$ long, about as long as ovary; anther 4-celled, drying black, suboblong, c. $1 \times 0.6 \mathrm{~mm}$. Pollen white, in monads. Gynophore $0.2-0.3 \mathrm{~mm}$ long. Ovary light green-brown, elliptic-oblong, $1.4-1.6 \times 0.8$ $\mathrm{mm}$, not laterally compressed, apex and base rounded, side with 6 main longitudinal ribs, commissural ribs 2, each paired and reduced, not as prominent as the main ribs and with a central longitudinal groove. Stigmas 2, diverging by c. 90 degrees, united at the base, elliptic, $0.3-$ $0.4 \times 0.1 \mathrm{~mm}$, (Fig. $2 \mathrm{E}, \mathrm{J}-\mathrm{N}$ ) widest towards base, tapering gradually to the acute apex, surface densely covered in minute acute papillate projections. Fruit dehiscing by a single valve. Seeds ellipsoid, pale brown, c. $0.6 \times 0.4 \mathrm{~mm}$. Figs 1, 2.

RECOGNITION. Similar to Ledermanniella jaegeri, differing in that cupuliform, approximately opposite and decussate leaves subtend the spathellae (not filiform spirally inserted leaves) and in the presence of sterile shoots with distichously arranged, tapering, ribbonlike leaves (absent in L. jaegeri), also in the stamen being longer than the ovary and monad pollen (not shorter than ovary and dyads).

DISTRIBUTION. Sierra Leone. Only known from the river bed of the Seli River in Koinadugu District, where it occurs in the proposed Yiben Reservoir area, to be permanently submerged when the construction of the proposed hydroelectric reservoir is implemented.

SPECIMEN EXAMINED. SIERRA LEONE. Koinadugu Distr., proposed Yiben Reservoir area, large rapids in Seli R., $\mathrm{N}$ of Yara village, $9^{\circ} 16^{\prime} 29.0^{\prime \prime} \mathrm{N} ; 1^{\circ} 34^{\prime} 50.6^{\prime \prime} \mathrm{W}, 300 \mathrm{~m}$ a.s.l., fl., fr., 6 April 2016, van der Burgt 1992 (holotype $\mathrm{K}$; isotypes $\mathrm{BM}, \mathrm{BR}, \mathrm{FBC}, \mathrm{G}, \mathrm{MO}, \mathrm{P}, \mathrm{SL}, \mathrm{WAG}, \mathrm{Z}$ ).

HABITAT \& ECOLOGY. Growing in a colony on bare, gneissic rocks forming the base of a river bed at a single set of rapids, submerged for most of the year, exposed and flowering only at end of dry season. Growing with no other vascular plant species.

CONSERVATION STATUS. Ledermanniella yiben is here assessed as Critically Endangered, using the Categories and Criteria of IUCN (2012), since a single global location is known on current evidence, containing, so far as is known, the entire world population of the species, which will be destroyed by permanent submergence under the waters of the reservoir of the proposed Yiben Hydroelectric Project if construction is realised. The area occupied by the species on the ground has been estimated by the second author as 0.25 Hectare (c. $50 \mathrm{~m} \times 50 \mathrm{~m}$ ). The area of occupancy (AOO) can be calculated using the preferred IUCN cell size for riverine species of $1 \mathrm{~km}^{2}$. The second and third authors have spent weeks surveying plants in the Yiben area but only found this species in an area of the Seli (Rokel) river bed about $50 \mathrm{~m}$ wide, and about as long, corresponding to a single rapid on the river. L. yiben was absent at rapids up and down the river from this location. The authors have also searched other fast flowing river systems in Sierra Leone for rheophytic species over the last seven years, yet have never before encountered this species. Many species of Podostemaceae in Africa are only known from a single waterfall or set of rapids (Cheek \& Haba 2016; Cheek et al. 2015; Cheek \& Ameka 2016; Cusset 1983, 1984).

It is hoped that searching further upriver (which has not been exhaustive) from the type and only known locality of Ledermanniella yiben might discover additional locations for the species but this is by no means a certainty. Such searches are now underway (March 2017) and attempts will be made at the same time to establish the species at other, secure sites in order to avoid its extinction. Establishing the species at another location will be a challenge. Translocation of species of Podostemaceae in Africa is not yet known to have been achieved successfully, yet it is not known that it has ever been attempted before.

ETYMOLOGY. Ledermanniella yiben is named for the proposed Yiben hydroelectric dam in Sierra Leone; the construction of which is likely to result in the extinction of the new species.

\section{Discussion}

\section{The homology of cupuliform leaves in African Podostemaceae}

In the first couplet of her key to the species of Ledermanniella subg. Ledermanniella, Cusset (1984) divides those species with "Leaves with sheath very enlarged, cupuliform, membranous" (that is, L. aloides (Engl.) C. Cusset, L. thalloidea (Engl.) C. Cusset and L. batangensis (Engl.) C. Cusset) from those without, including those with leaf sheaths which are oblong, such as L. sanagensis C. Cusset. In fact, intermediates occur, such as the elliptic leaf sheaths of L. lunda Cheek. L. aloides itself often has laterally compressed leaf sheaths which are then not truly cupuliform. In L. thalloidea and L. batangensis the leaf-sheath origin of the cupuliform structure is especially clear since a filiform leaf-blade arises peltately from near the apex of the dorsal surface of the cupuliform structure. The presence of a pair of short triangular stipules on each side of the apex of the cupuliform structure in L. batangensis (Cusset 1987) further confirms the homology, since these stipules are typical of those that appear sporadically on the margins of leaf sheaths in 
other African Podostemaceae, such as in Saxicolella marginalis (G. Taylor) Cheek.

The cupuliform structures of Ledermanniella yiben lack filiform blades, but occasionally a small peltate protuberance can be found on their dorsal surface which may indicate a vestigial leaf-blade. This same condition occurs in Macropodiella pellucida (Engl.) C. Cusset, in which the cupuliform structures (leaf-bases), as in L. yiben, also occur in short shoots and which also subtend a terminal spathellum.

It is difficult not to conclude that these last two species have a sister relationship despite their current placement in different genera. This generic placement is based on a single floral character, the presence of laterally flattened ovary or not, which further research may show to be labile. Vegetative and architectural characters may be as important or sometimes a better indicator of evolutionary relationships of species than floral characters hitherto exclusively used in defining the genera of African Podostemaceae (Cusset 1973, 1974, 1978, 1983, 1984, 1987). Genera such as Macropodiella may be artificial as currently defined (Cheek \& Ameka 2016) as is Ledermanniella (Thiv. et al. 2009).

We have seen that cupuliform leaves of leaf sheath origin occur in African Podostemaceae and that they may be a modification of the widespread leaf type that occurs in the group, in which the leaf is long and slender, ribbon-like or terete, with a dilated, sheathing base attaching it to the stem. That these cupuliform leaves always occur on short shoots and subtend spathellae suggests that their function is to protect the developing spathellum rather than to photosynthesise. Essentially, they function as bracts.

\section{Dyad and monad lineages of Ledermanniella}

Thiv et al. (2009) and Koi et al. (2012) showed that Ledermanniella is divided into Ledermanniella-Monad and Ledermanniella-Dyad lineages based on molecular phylogenetic evidence. L. yiben has monad pollen. Attempts to find morphological synapomorphies that support the monad lineage have not yet been successful.

\section{Recent botanical novelties in Sierra Leone}

Ledermanniella yiben is among a host of new species that have been brought to light and published from Sierra Leone in recent years, following decades of relative inactivity in plant species discovery in that country and its neighbours. This has mostly been driven by increased industrial activity and associated Environmental Impact Assessment work, but also greater ease of accessibility following reduced conflict. Examples of such newly discovered species in Sierra Leone are: Dactyladenia globosa Jongkind (2012), Pseudovigna sulaensis R. Clark \& Burgt (Clark et al. 2012), Xysmalobium samouritourei Goyder (2009), Stylochaeton pilosus Bogner (2011),
Isoglossa dispersa I. Darbysh. \& L. J. Pearce (Darbyshire et al. 2011), Gilbertiodendron tonkolili Burgt \& Estrella (Estrella et al. 2012), Eriocaulon cryptocephalum S. M. Phillips \& Mesterházy and E. tingilomum S. M. Phillips \& Mesterházy (2015), E. sulanum S. M. Phillips \& Burgt and E. petraeum S. M. Phillips \& Burgt (Phillips et al. 2012), Napoleonaea alata Jongkind (Prance \& Jongkind 2015) and Psychotria samoritourei Cheek (Cheek \& Williams 2016). Just over the border in Ivory Coast examples include Macropodiella cussetiana Cheek (Cheek \& Ameka 2016), and in Guinea Striga magnibracteata Eb. Fisch. \& I. Darbysh. (Fischer et al. 2011) and Gymnosiphon samoritoureanus Cheek (Cheek \& van der Burgt 2010). Even a new rheophytic genus, Karima Cheek \& Riina has recently been discovered in Sierra Leone (Cheek et al. 2016).

\section{Acknowledgements}

The authors thank ERM for co-ordinating the field studies and for financing the work that resulted in this discovery. Mrs K. M. B. Garnett, Director of the Conservation and Wildlife Management Unit of the Ministry of Agriculture, Forestry and Food Security kindly provided permission to perform botanical research in Sierra Leone. Two anonymous reviewers made helpful comments on an earlier version of this manuscript. Janis Shillito typed the manuscript.

Open Access This article is distributed under the terms of the Creative Commons Attribution 4.0 International License (http://creativecommons.org/ licenses/by/4.0/), which permits unrestricted use, distribution, and reproduction in any medium, provided you give appropriate credit to the original author(s) and the source, provide a link to the Creative Commons license, and indicate if changes were made.

\section{References}

Beentje, H. (2005). Podostemaceae. Flora of Tropical East Africa. Balkema, Netherlands.

Bogner, J. (2011). Four new species of Culcasia and Stylochaeton (Araceae) from tropical Africa. Willdenowia 41: 57 - 66. doi:10.3372/wi.41.41106 (available via http://dx.doi.org/)

Cheek, M. (2003). A new species of Ledermanniella (Podostemaceae) from western Cameroon. Kew Bull. 58: 733 - 737. doi: $10.2307 / 4111153$

\& Ameka, G. (2008). Ledermanniella pollardiana sp. nov. (Podostemaceae) from western Cameroon. Nordic J. Bot. 26: 214 - 217. doi: 10.1111/j.17561051.2008.00162.x

$\&$ (2016). Macropodiella cussetiana (Podostemaceae) a new species from Côte d'Ivoire. Kew Bull. 71: 21. doi: 10.1007/S12225-016-9634-9. 
\& van der Burgt, X. (2010). Gymnosiphon samoritoureanus (Burmanniaceae) a new species from Guinea, with new records of other achlorophyllous heteromycotrophs. Kew Bull. 65 (1): 83 - 88. doi: $10.1007 /$ s12225-010-9180-9

\& Haba, P. M. (2016). Inversodicraea Engl. resurrected and I. pepehabai sp. nov. (Podostemaceae), a new submontane forest species from the Republic of Guinea. Kew Bull. 71: 55. doi: 10.1007/S12225-016-9673-2

, Lopez Poveda, L. \& Darbyshire, I. (2015).

Ledermanniella lunda sp. nov. (Podostemaceae) of Lunda Norte, Angola. Kew Bull. 70: 10. doi: 10.1007/S12225-015-9559-8

, Challen, G., Lebbie, A., Banks, H., Barberá, P. \& Riina, R. (2016). Discovering Karima (Euphorbiaceae) a New Crotonoid Genus from West Tropical Africa Long Hidden within Croton. PLOS ONE. doi: 10.1371/journal.pone.0152110

\& Williams, T. (2016). Psychotria samoritourei (Rubiaceae), a new liana species from Loma-Man in Upper Guinea, West Africa. Kew Bull. 71: 19. doi: 10.1007/S12225-016-9638-5

Clark, R., van der Burgt, X. \& Banks, H. (2012). A synopsis of Pseudovigna (Leguminosae: Papilionoideae) including a new species, P. sulaensis, from Sierra Leone. Kew Bull. 66: 589 599. doi: 10.1007/s12225-011-9314-8

Cusset, C. (1973). Contribution à l'étude des Podostemaceae. III Le genre Stonesia. Bull. Mus. Natl. Hist. Nat., 4e sér., 6, B, Adansonia 13: 307 - 312. (1974). Contribution à l'étude des Podostemaceae. VI Les genres Ledermanniella, Monandriella et Inversodicraea. Bull. Mus. Natl. Hist. Nat., 4e sér., 6, B, Adansonia 14: 271 - 275.

(1978). Contribution à l'étude des Podostemaceae. V Le genre Macropodiella Engl. Bull. Mus. Natl. Hist. Nat., 4e sér., 6, B, Adansonia 6: 293 - 303.

(1983). Contribution à l'étude des Podostemaceae. 7 Ledermanniella Engl. Sous-genre Phyllosma C. Cusset. Bull. Mus. Natl. Hist. Nat., 4e sér., 5, B, Adansonia 4: 361 -390 .

(1984). Contribution à l'étude des Podostemaceae. 8 Ledermanniella Engl. Sous-genre Ledermanniella C. Cusset. Bull. Mus. Natl. Hist. Nat., 4e sér., 6, B, Adansonia 3: 249 - 278.

(1987). Podostemaceae. Flore du Cameroun 30. MESRES, Yaoundé, Cameroun.

Darbyshire, I., Pearce, L. \& Banks, H. (2011). The genus Isoglossa (Acanthaceae) in West Africa. Kew Bull. 66: 425. doi: 10.1007/s12225-011-9292-x

Estrella, M. de la, van der Burgt, X. M., Mackinder, B. A., Devesa, J. A., James, M. S. \& Hawthorne, W. D. (2012). Gilbertiodendron tonkolili sp. nov. (LeguminosaeCaesalpinioideae) from Sierra Leone. Nordic J. Bot. 30: 136 - 143. doi: 10.1111/j.1756-1051.2012.01357.x

Fischer, E., Darbyshire, I. \& Cheek, M. (2011). Striga magnibracteata (Orobanchaceae) a new species from
Guinée and Mali. Kew Bull. 66: 441 - 445. doi: 10.1007/s12225-011-9296-6

Goyder, D. J. (2009). Xysmalobium samoritourei (Apocynaceae: Asclepiadoideae), a new species from the Guinea Highlands of West Africa. Kew Bull. 63: 473 - 475. doi: 10.1007/s12225-008-9059-1

Index Herbariorum (continuously updated). A global directory of public herbaria and associated staff. New York Botanical Garden's Virtual Herbarium. http://sweetgum.nybg.org/ih/

IPNI (continuously updated).The International Plant Names Index. http://ipni.org/.

IUCN (2012). IUCN Red List Categories and Criteria: Version 3.1. Second edition. IUCN, Gland and Cambridge.

Jongkind, C. (2012). Description of Dactyladenia globosa (Chrysobalanaceae), a new tree species from Sierra Leone, Liberia and Côte d'Ivoire. Pl. Ecol. Evol. 145 (1) : 126 - 128. doi: 10.5091/plecevo.2012.594

Kita, Y., Satoshi, K., Rutishauser, R. \& Kato, M. (2008). A New Species of Ledermanniella (Podostemaceae) from Cameroon. Acta Phytotax.Geobot. 59 (3): 223 - 227.

Koi, S., Kita, Y., Hirayama, Y., Rutishauser, R., Huber, K. A. \& Kato, M. (2012). Molecular phylogenetic analysis of Podostemaceae: implications for taxonomy of major groups. Bot. J. Linn. Soc. 169: 461 - 492.

Phillips, S. M., van der Burgt, X. M. \& Kanu, K. M. T. (2012). Two new species of Eriocaulon (Eriocaulaceae) from Sierra Leone. Kew Bull. 67: 273 - 280. doi:10.1007/s12225-012-9353-9

\& Mesterházy, A. (2015). Revision of small ephemeral species of Eriocaulon (Eriocaulaceae) in West Africa with long involucral bracts. Kew Bull. 70 (5) doi: 10.1007/s12225-014-9557-2

Prance, G. T. \& Jongkind, C. C. H. (2015). A revision of African Lecythidaceae. Kew Bull. 70 (6). doi: $10.1007 / \mathrm{s} 12225-014-9547-4$

Rial, A. (2002). Une nouvelle espèce de Macropodiella (Podostemaceae) de Guinée Équatoriale. Adansonia 24 (2): $295-297$.

Rutishauser, R. (2004). Podostemaceae of Africa and Madagascar: keys to genera and species, including genera description, illustrations to all species known, synonyms, and literature cited. www.systbot.uzh.ch/ static/podostemaceae/keys/podostemaceae_key.pdf

Schenk, J. J. \& Thomas, D. W. (2004). A New Species of Ledermanniella (Podostemaceae) from Cameroon. Novon 14 (2): 227 - 232.

, Herschlag, R., Thomas, D. W. (2015). Describing a New Species into a Polyphyletic Genus: Taxonomic Novelty in Ledermanniella s.l. (Podostemaceae) from Cameroon. Syst. Bot. 40 (2): 539 - 552. doi: 10.1600/ $036364415 \times 688330$

Thiv, M., Ghogue, J.-P., Grob, V., Huber, K., Pfeifer, E. \& Rutishauser, R. (2009). How to get off the mismatch at the generic rank in African Podostemaceae? Pl. Syst. Evol. 283: 57 - 77. doi: 10.1007/s00606-009-0214-4 